\title{
ELIZABETH GASKELL
}


Women Writers

General Editors: Eva Figes and Adele King

\section{Published titles}

Margaret Atwood, Barbara Hill Rigney

Jane Austen, Meenakshi Mukherjee

Elizabeth Bowen, Phyllis Lassner

Anne Brontë, Elizabeth Langland

Charlotte Brontë, Pauline Nestor

Emily Brontë, Lyn Pykett

Fanny Burney, Judy Simons

Willa Cather, Susie Thomas

Colette, Diana Holmes

Ivy Comptor-Burnett, Kathy Justice Gentile

Emily Dickinson, Joan Kirkby

George Eliot, Kristin Brady

Elizabeth Gaskell, Jane Spencer

Sylvia Plath, Susan Bassnett

Christina Stead, Diana Brydon

Eudora Welty, Louise Westling

Edith Wharton, Katherine Joslin

Forthcoming

Elizabeth Barrett Browning, Marjorie Stone Doris Lessing, Margaret Moan Rowe Katherine Mansfield, Diane DeBell Toni Morrison, Nellie McKay Jean Rhys, Carol Rumens Christina Rossetti, Linda Marshall Stevie Smith, Romana Huk Muriel Spark, Judith Sproxton Gertrude Stein, Jane Bowers Virginia Woolf, Clare Hanson 


\section{Women Writers}

\section{Elizabeth Gaskell \\ Jane Spencer}


ISBN 978-0-333-37947-9 ISBN 978-1-349-22617-7 (eBook)

DOI 10.1007/978-1-349-22617-7

(1) Jane Spencer 1993

Softcover reprint of the hardcover 1st edition 1993

All rights reserved. For information, write:

Scholarly and Reference Division,

St. Martin's Press, Inc., 175 Fifth Avenue,

New York, N.Y. 10010

First published in the United States of America in 1993

ISBN 978-0-312-06058-9

Library of Congress Cataloging-in-Publication Data

Spencer, Jane.

Elizabeth Gaskell / Jane Spencer.

p. cm.- (Women writers)

ISBN 978-0-312-06058-9

1. Gaskell, Elizabeth Cleghorn, 1810-1865-Criticism and interpretation. 2. Women and literature-EnglandHistory-19th century. I. Title. II. Series.

PR4711.S67 1993

$823^{\prime} .8-\mathrm{dc} 20$

92-30539

CIP 


\section{Contents}

Acknowledgements vi

Editors' Preface vii

Notes on the Texts viii

1. Warring Members: Elizabeth Gaskell, Writer 1

2. Giving Utterance: Mary Barton 32

3. Improper Women:

Ruth and The Life of Charlotte Brontë 51

4. Changes: Cranford and North and South 75

5. History and Tyranny: Sylvia's Lovers 96

6. Household Goodness:

'Cousin Phillis', Wives and Daughters 116

$\begin{array}{ll}\text { Notes } & 141\end{array}$

Selected Bibliography $\quad 147$

Index 152 


\section{Acknowledgements}

An earlier version of chapter 2 appeared in The Gaskell Society Journal, vol. 2, 1988, as 'Mary Barton and Thomas Carlyle'. I am grateful to the editor, Alan Shelston, for permission to use the material here. I would also like to thank John Chapple and Arthur Pollard, the editors of The Letters of Mrs Gaskell, and Manchester University Press, the publishers, for permission to quote from their edition.

Thanks go to Ian Campbell, Gareth Roberts, Peter Keating, and Valerie Shaw, who helped me at various times by discussing Gaskell with me, and especially to Josephine McDonagh, who read and commented on chapters in draft. I would also like to thank all the students who took the special option on Elizabeth Gaskell in Edinburgh in the years 1985-7, and those who took the 'Women's Writing' option in Exeter in the years 1989-92. Their stimulating discussions of Gaskell helped me enormously.

I am very grateful to Marion Shaw and Patsy Stoneman, whose course 'Women in Literature and Society' first introduced me to Gaskell, and to much else.

Thanks to Hugh and Kate, for being there.

JANE SPENCER 


\section{Editors' Preface}

The study of women's writing has been long neglected by a male critical establishment both in academic circles and beyond. As a result, many women writers have either been unfairly neglected or have been marginalised in some way, so that their true influence and importance has been ignored. Other women writers have been accepted by male critics and academics, but on terms which seem, to many women readers of this generation, to be false or simplistic. In the past the internal conflicts involved in being a woman in a male-dominated society have been largely ignored by readers of both sexes, and this has affected our reading of women's work. The time has come for a serious reassessment of women's writing in the light of what we understand today.

This series is designed to help in that reassessment.

All the books are written by women because we believe that men's understanding of feminist critique is only, at best, partial. And besides, men have held the floor quite long enough.

EVA FIGES

ADELE KING 


\section{Notes on the Texts}

CCP Cranford, and 'Cousin Phillis', in Cranford/ Cousin Phillis (Harmondsworth: Penguin, 1976).

CPET 'Curious, If True', in Cousin Phillis and Other Tales (Oxford: World's Classics, 1981).

L The Letters of Mrs Gaskell, ed. J. A. V. Chapple and Arthur Pollard (Manchester: Manchester University Press, 1966).

$L C B$ The Life of Charlotte Brontë (Harmondsworth: Penguin, 1975).

MB Mary Barton (Harmondsworth: Penguin, 1970).

NS North and South (Harmondsworth: Penguin, 1977).

$R \quad$ Ruth (Oxford: World's Classics, 1985).

SL Sylvia's Lovers (Oxford: World's Classics, 1982).

WD Wives and Daughters (Oxford: World's Classics, 1987). 